\title{
Design of a modified natural Egyptian solar house
}

\author{
Hanaa M. Farghally, Amal A. Hassan, Ninet M. Ahmed, Faten H. Fahmy \\ Photovoltaic Cells Department, Electronics Research Institute, Cairo, Egypt
}

\begin{tabular}{l}
\hline \hline Article Info \\
\hline Article history: \\
Received Jan 6, 2019 \\
Revised Apr 29, 2019 \\
Accepted Sep 27, 2019 \\
\hline Keywords: \\
Modelling \\
Solar house \\
Solar water heating \\
Space heating
\end{tabular}

\begin{abstract}
The rate of increase in energy consumption and high costs in addition to the depletion of existing resources has a significant impact on our standard of living for next generations. In this case, the priority is to develop alternative cost-effective sources for powering the residential and non-residential buildings. This paper proposes and develops a design of a modified small two-story residential solar house for a medium-sized family located in Cairo, Egypt. This modified solar house meets almost all its energy demands including space heating by using solar air collector with a pebble storage unit in winter and a summer cooling system using wind catcher theory. Hot water is obtained throughout the day by using a steel sheltered water storage tank with a capacity of 1000 liter. Finally, the proposed heating system of the solar house is sized and modeled.
\end{abstract}

Copyright () 2020 Institute of Advanced Engineering and Science. All rights reserved.

Corresponding Author:

Hanaa Mohamed Farghally, Photovoltaic Cells Department, Electronics Research Institute,

21 Joseph Tito st., El-Nozha El-Gededa, Cairo, Egypt.

Email: farghally5555@gmail.com

\section{INTRODUCTION}

In Egypt, Energy demand for residential buildings is continuously increasing due to global population growth and improved living standards [1]. Building cooling using air-conditioners became the largest consumer of electricity. More than half of the urban peak load of energy which accounts for nearly $60 \%$ of nation's peak power demand is consumed to satisfy air conditioning demands [2]. However, fossil fuels, the current main energy source, are being consumed in a random increasing manner, even though they are non-renewable and their global quantity is limited [3-5]. Consequently, environmental pollution and global warming are fearfully increasing. Based on this fact, worldwide governments are working to increase the share of renewable energy sources, reduce energy consumption and accordingly reduce environmental pollution $[6,7]$.

Therefore, for energy saving, it is too necessary to use the natural cooling methods and solar thermal collector systems used for space heating and hot water production. A solar house is fully powered by using solar energy in order to minimize the use of traditional energy sources. This includes the design elements that take advantage of the sun to light and heat the house, to heat the water, and to set up a favorable flow of air (space heating). Many solar houses contain a solar mass that will absorb the heat during the day and release it slowly at night $[8,9]$.

Many researches have addressed the design of a solar house. In [10], a design of a net-zero solar house is proposed, while [11, 12] developed an evaluation index system for the design of a solar house. An optimal design of an active solar house is presented in [13] which clarify the advantages and disadvantages of utilizing solar house. Solar houses can be classified into two classes; traditional and advanced solar house. The traditional solar house system uses direct and indirect sunlight in the lighting of buildings during the daylight. The advanced solar house system is used only for the daytime buildings such as companies and banks. In this case, the lighting of the building includes only daytime lighting for all indoor 
and outdoor rooms as well as central heating of the building in winter and central air conditioning of the building in summer [14]. The building is also supplied with hot water and it includes a small station for the production of electricity to feed the electrical loads of the building. But this system is complex and expensive. So, in this paper, a modified design of a small two-story residential solar house is presented. The design of the modified solar house located in Cairo, Egypt is proposed for a medium-sized family and the area of the house is about 110 square meters. In this work, the performance of the thermal system is of major concern, therefore the sizing and modelling of the thermal system is considered only. The authors will consider the sizing and modelling of the summer cooling system in another paper.

\section{SOLAR HOUSE LOCATION}

Cairo is chosen as the site to locate the suggested solar house. The specific geographical location of Cairo city is at a location of $30^{\circ} 05^{\prime} \mathrm{N}$ latitude, $31^{\circ} 17^{\prime} \mathrm{E}$ longitude and elevation $34.4 \mathrm{~m}$. The annual average global solar radiation of $5.21 \mathrm{kWh} / \mathrm{m}^{2} /$ day with a clearness index of 0.597 . Solar radiation, ambient temperature and the specific geographical location data for this city is obtained from the Egyptian solar radiation Atlas [15].

\subsection{Solar radiation data}

Solar heating systems can be sized on the basis, of, monthly average daily radiation on a horizontal surface; the values of solar radiation for the selected site, Cairo are listed for each month in Figure 1.

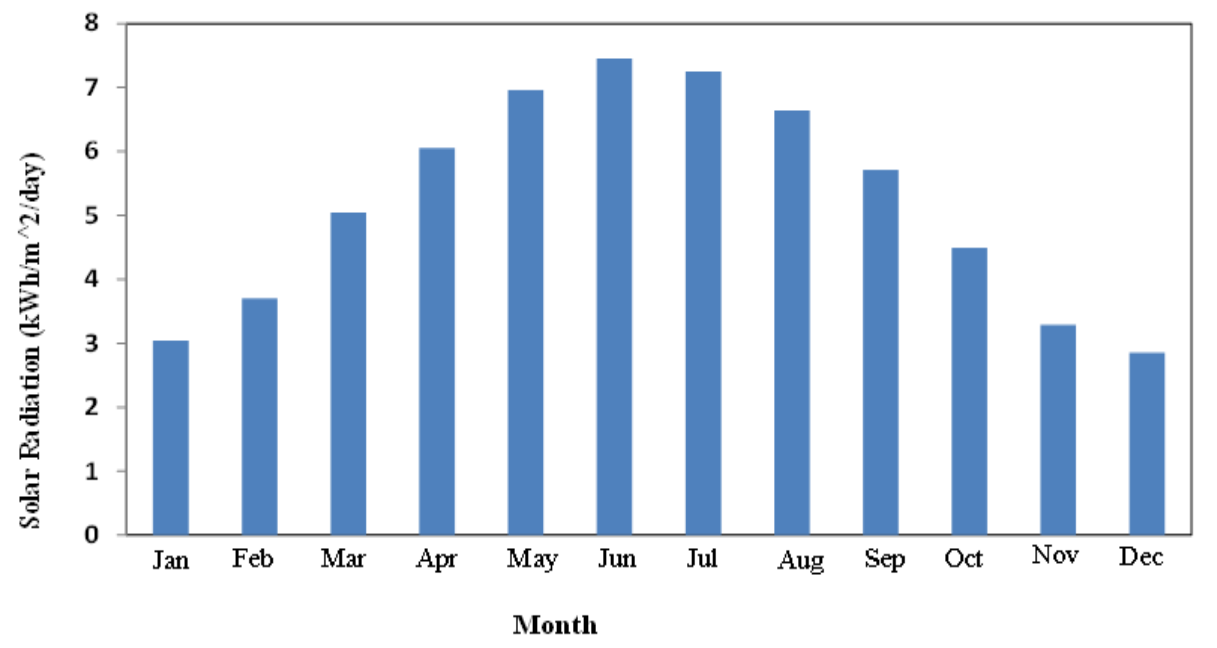

Figure 1. Daily irradiation in Cairo on a horizontal surface

\section{PROPOSED MODIFIED SOLAR HOUSE}

A small building is designed to have two stories for a medium-sized family. The building consists of a ground floor which includes 2 bedrooms, kitchen, grand hall, bathroom and entrance. The upper floor includes a large bedroom that is accessed by a wooden staircase from the ground floor. The house is about 110 square meters. The house is illuminated using natural light during daylight while it is illuminated by artificial light sources at night and during cloudy hours. A winter heating system using solar air collector with a pebble storage unit is designed. Hot water is obtained throughout the day by sheltered water storage tank; this method is the most efficient and cheapest way to heat water. Space heating for the proposed solar house is done through the use of solar air heating panels. Figure 2 shows a schematic diagram of the proposed solar house. The house is designed to optimize the utilization of solar energy. Figure 3 clarifies the plan view of the proposed solar house. The proposed solar house has major features that can be summarized as the following: lightweight building, active solar heating and north-south direction. It is constructed from strong iron sections and the wallsare made of compressed cardboard wood to prevent against fire [16]. 


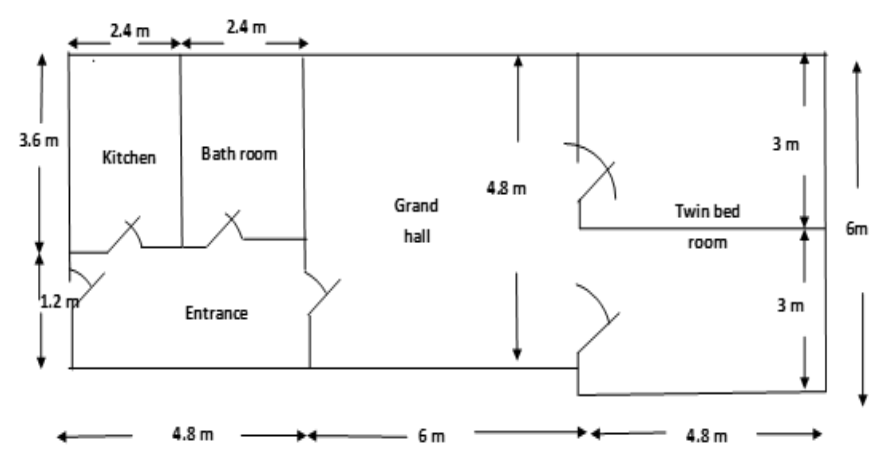

Figure2. Schematic diagram of the proposed solar house

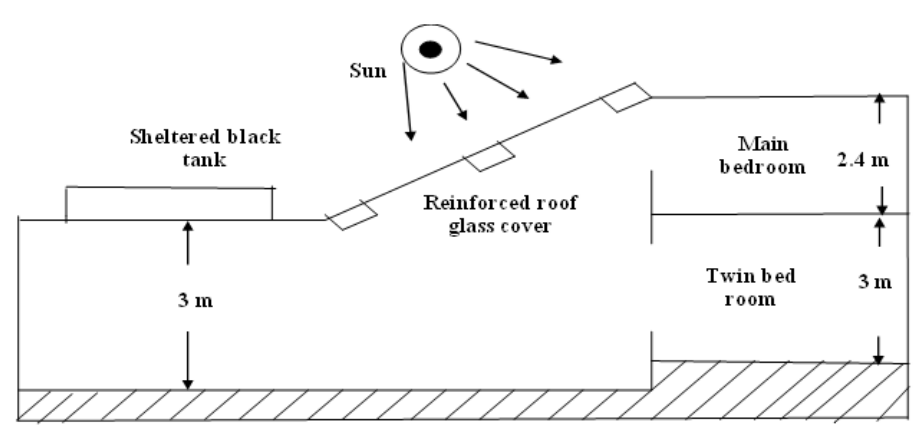

Figure 3. Plan view of the proposed solar house

\section{SOLAR HOUSE SPACE HEATING SYSTEM}

Space heating by air circulation is one of the simplest methods of heating. Figure 4 represents a schematic diagram of the proposed space heating system for the solar house. The main components of this system are:(1) solar air-heating collector have a flat absorber; (2) a pebble-bed heat storage unit to and from which heat is transferred by circulating air through the bed; (3) an air handling module comprising automatic dampers and blower(s) [17]. The solar collector absorbs solar radiation and converts it to a heat air for space heating. Air is circulated from one end, of the collector to the other. The house is heated directly from the collector. Cool air from the house is returned to the collector for reheating. The heat storage unit utilizes the heat exchange and heat storage characteristics of dry pebbles, which is the most practical storage medium for use with air heating collectors. When the quantity of heat is more than that required for house space, solar heated air is routed through the storage unit as in Figure 4, thereby heating the pebbles; the cool air returns to the collector for reheating. By positioning the three-way dampers and controlling the blowers on or off, three "modes" of operation are probable:

- Heating the house directly from the collector

- Heating the storage unit from the collector

- Heating the house from the storage unit

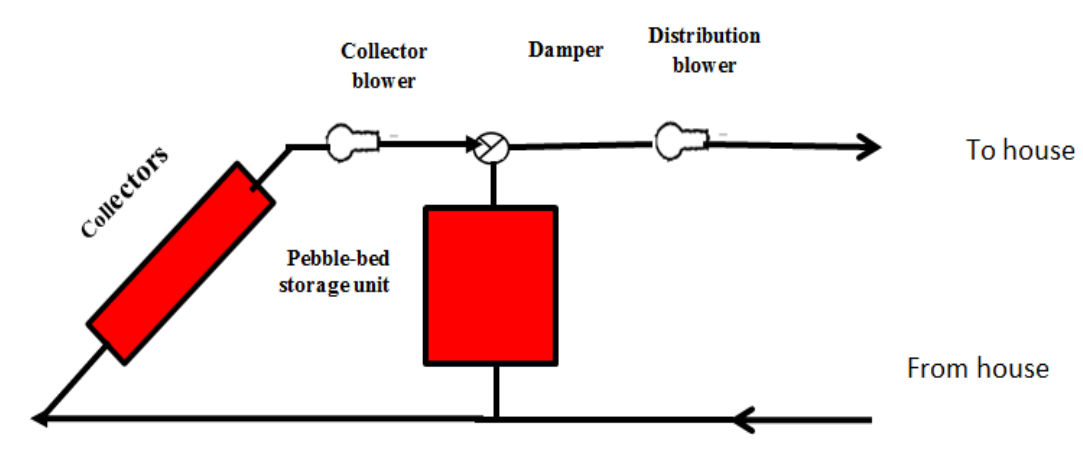

Figure 4. Schematic diagram of proposed space heating system 


\subsection{Space heat load factors}

The heat load depend on many factors; the area of walls and ceiling of the house, the heat loss, transmission coefficients through the walls and ceiling, the difference between the indoor and outdoor temperature and the infiltration of cold air into the house. The different heat loss rates are calculated as follows:

a. Heat loss rate

The rate of heat loss, $\dot{Q}_{h l}$, in Btu/hr through a surface of area, A, with a temperate difference across the two sides of the surface of $\left(T_{i}-T_{o}\right)$, is $[18,19]$ :

$$
\dot{Q_{h l}}=\bar{U} A\left(T_{i}-T_{o}\right)
$$

Where, $\bar{U}$ is the overall heat loss coefficient from walls, ceiling, floor or glass $\left(\mathrm{Btu} / \mathrm{hr} . \mathrm{ft}^{2}{ }^{\circ} \mathrm{F}\right)$, A is the net area of walls, ceiling, floor or glass $\left(\mathrm{ft}^{2}\right), T_{i}$ is the inside design temperature $\left({ }^{\circ} \mathrm{F}\right), T_{o}$ is the outside design temperature $\left({ }^{\circ} \mathrm{F}\right)$.

b. Infiltration heat loss

The cold air that enters the house through open doors, windows and cracks constitutes a heat loss because that cold air displaces the warm room air. Consequently, the cold air must be heated to room temperature again. The air ventilation can be calculated as follows:

$$
V_{v}=A C H \times A \times H
$$

Where, $V_{v}$ is the volumetric air flow rate in cubic feet per hour, $A C H$ is the air change per hour which can be considered to be 0.15 to 0.5 . $A$ is the area of the space in $\mathrm{ft}^{2}, H$ is the height of the room in $\mathrm{ft}$.

The infiltration heat loss rate $\left(\dot{Q}_{f}\right)$ in Btu/hr can be computed from:

$$
\dot{Q}_{f}=V_{v} \rho_{\text {air }} C p_{\text {air }}\left(T_{i}-T_{o}\right)
$$

Where, $\rho_{\text {air }}$ is the density of the air $\left(0.0765 \mathrm{lb} / \mathrm{ft}^{3}\right), C p_{\text {air }}$ is the specific heat capacity of air $\left(0.24 \mathrm{Btu} / \mathrm{lb} .{ }^{\circ} \mathrm{F}\right),\left(T_{i}-T_{o}\right)$ is the difference in inside and outside air temperatures $\left({ }^{\circ} \mathrm{F}\right)$.

\subsection{Space heating load}

The Sum of the heat transmission losses through the house enclosure and the infiltration losses is the designed hourly heat loss rate for the house. The space heating load for the house based on January heating degree- day (DD) is calculated from the design heat loss rate as follows [17]:

$$
\text { Space heating load }\left(\frac{B t u}{D D}\right)=\frac{\text { Design heat loss rate }}{\text { Design temperature difference }} \times 24
$$

The monthly heating loads are then calculated using degree-day values as:

$$
\text { Heating load }(B t u)=\frac{B t u}{D D}(\text { Heating degree }- \text { Days })
$$

\subsection{Space heating collector modeling}

The air in the collector will absorb the sun's energy with the rate $\left(\dot{Q}_{\mathrm{abs}}\right)[18]$ :

$$
\dot{\mathrm{Q}}_{\mathrm{abs}}=\eta_{\mathrm{eff}} \mathrm{A}_{\mathrm{c}} \mathrm{G}_{\mathrm{r}}
$$

and will loss a certain amount of heat energy to its surrounding $\left(\dot{\mathrm{Q}}_{\text {loss }}\right)$, given by [19] :

$$
\dot{\mathrm{Q}}_{\text {loss }}=\overline{\mathrm{U}}_{\mathrm{c}} \mathrm{A}_{\mathrm{c}}\left(\mathrm{T}_{\mathrm{c}, \text { out }}-\mathrm{T}_{\mathrm{amb}}\right)
$$

Where, $\eta_{\text {eff }}$ is the effective absorbance of collector's cover, $\eta_{\text {eff }}=\tau \alpha, \tau$ is the transmissivity of the collector (fraction of incident energy transmitted), $\alpha$ is the absorptivity of the collector (fraction of insolation), $\mathrm{A}_{\mathrm{c}}$ is the collector's area $\left(\mathrm{ft}^{2}\right), \mathrm{G}_{\mathrm{r}}$ is the solar radiation $\left(\mathrm{Btu} / \mathrm{ft}^{2}\right), \overline{\mathrm{U}}_{\mathrm{c}}$ is the overall heat loss coefficient $\left(\mathrm{Btu} / \mathrm{ft}^{2 \circ} \mathrm{F}\right), \mathrm{T}_{\mathrm{c}, \text { out }}$ is the average temperature at the collector's outlet $\left({ }^{\circ} \mathrm{F}\right), \mathrm{T}_{\mathrm{amb}}$ is the ambient temperature $\left({ }^{\circ} \mathrm{F}\right)$. Thus, an energy balance [17] of the collector $\left(\dot{\mathrm{Q}}_{\mathrm{c}, \text { out }}\right)$ is represented as the following equation:

$$
\dot{Q}_{c, \text { out }}=\dot{Q}_{a b s}-\dot{Q}_{\text {loss }}
$$


By substituting using (6) and (7), (8) can be rewritten as follows:

$$
\dot{m} C_{p a}\left(T_{c, \text { out }}-T_{c, \text { in }}\right)=\eta_{\text {eff }} A_{c} G_{r}-\bar{U}_{c} A_{c}\left(T_{c, \text { out }}-T_{a m b}\right)
$$

Where, $\dot{Q}_{c, \text { out }}$ is the rate of change of air energy at the collector outlet, $\dot{m}$ is the air mass flow rate (lb/s), $T_{c, i n}$ is the air temperature at the collector inlet $\left({ }^{\circ} \mathrm{F}\right), C_{p a}$ is the specific heat of air $\left(\mathrm{Btu} / \mathrm{lb}\right.$. $\left.{ }^{\circ} \mathrm{F}\right)$. The thermal efficiency of the solar collector $\left(\eta_{c}\right)$ is the ratio of the useful collected energy and the incident solar radiation on the collector's plane and can be calculated using the following equation [17]:

$$
\eta_{c}=\frac{\dot{Q}_{c, o u t}}{A_{c} G_{r}}
$$

\subsection{Space heating system sizing}

Solar heating system is sized to provide a desired fraction of the total heating load of the house. A simple procedure based, on average conditions is presented to calculate collector area. From the collector area determined, the sizes of other components are established. Rules of thumb are given as a guide in sizing the entire system from a given collector area.

\subsubsection{Collector area calculation}

The desired collector area is dependent upon the January solar radiation, $G_{r}$, and January heating load, L, of the house. The area of collectors needed is determined by [16]:

$$
A_{c}=\frac{0.9 \times L}{\mathrm{G}_{\mathrm{r}}}
$$

\subsubsection{Storage unit sizing}

The recommended size of storage unit relative to the collector area is one-half to one cubic foot of pebbles per square foot of collector area for an air heating system. The storage unit is placed within the house enclosure. An indoor storage location has the advantage that it is protected from moisture and cold, and the heat loss from the storage unit will assist in heating the house in winter. The recommended size of storage unit as calculated according to the rule of thumb presented in Table 1 will be $79.53 \mathrm{ft}^{3}$ of rock.

\subsubsection{Rules of thumb for sizing}

Rules of thumb are given to guide in sizing the entire air heating system from a given collector area. Rules of thumb for air solar systems are presented in Table 1.

Table 1. Rules of thumb for sizing

\begin{tabular}{ll}
\hline Items & Rules of thumb for sizing \\
\hline Collector slope & Latitude $+15^{\circ}$ \\
Collector air flow rate & 1.5 to $2 \mathrm{CFM} / \mathrm{ft}^{2}$ of collector \\
Pebble bed storage size & $1 / 2$ to $1 \mathrm{ft}^{3}$ of rock $/ \mathrm{ft}^{2}$ of collector \\
Pebble size & $3 / 4 "$ to $1 "$ concrete aggregate \\
Rock depth & 4 to 8 feet in air flow direction \\
\hline
\end{tabular}

\section{DOMESTIC SHELTERED WATER STORAGE TANK}

The water heating system illustrated in Figure 5 can be designed and installed easily using locally available materials and components. So, this system is easy to maintain and cost-effective. The solar water heating system consists of a steel storage tank of a capacity of 1000 liter installed above the roof of the kitchen and bathroom as indicated in Figure 2. So, no heat is lost by evaporation. The water tank is coated using black, coal tar enamel paint. This black outer surface has a good absorption of solar radiation $(\alpha=.9)$, some of this absorbed heat is then passed to water by conduction. This heater is cheap, easy to make and gives moderately hot water $\left(20^{\circ} \mathrm{C}\right.$ above ambient). The heat loss of the system is reduced by insulating the bottom of the tank with polystyrene sheets of $1 \mathrm{~cm}$ thickness. The tank can also be sheltered from the wind to reduce the convective loss. This will be done by encapsulating the tank in a covered box with a transparent glass Lid $3.0 \mathrm{~cm}$ above and $10 \mathrm{~cm}$ insulation below [20]. 


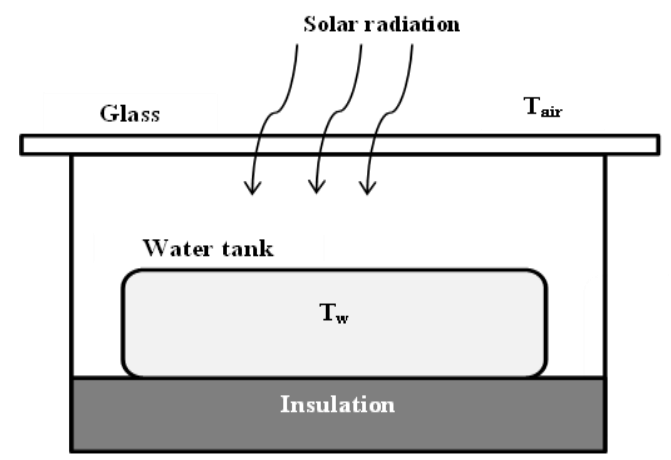

Figure 5. Schematic diagram of proposed sheltered water storage tank

The tank and its content (water inside it) will be treated as a composite system. The temperature at which heat is lost from the system is the outside temperature of the tank $\left(T_{\text {tank }}\right)$ to a first approximation $T_{\text {tank }}=T_{w}$, the mean temperature of the water [21]. The heat balance of the water inside the tank is given by $[18,19,21]$ :

$$
m_{w} C_{w} \frac{d T_{w}}{d t}=\tau \alpha A_{c} G_{r}-U_{\text {tank }} A_{\text {tank }}\left(T_{w}-T_{\text {air }}\right)
$$

Where, $T_{w}$ is the mean temperature of the water $(\mathrm{K}), m_{w}$ is the mass flow rate of water $(\mathrm{kg} / \mathrm{s}), C_{w}$ is the specific heat of water $(\mathrm{kJ} / \mathrm{kg} . \mathrm{K}), A_{\text {tank }}$ is the tank's area $\left(\mathrm{m}^{2}\right), U_{\text {tank }}$ is the overall thermal loss coefficient $\left(\mathrm{kW} / \mathrm{m}^{2} \mathrm{~K}\right)$.

\section{SUMMER COOLING USING MALQAF}

The malqaf or wind catcher is dominantly used in Egypt as early as the pre-dynastic period due to its simplicity and ease of implementation. In this method some natural vents face north to catch the cool prevailing winds. It is based on the natural ventilation by allowing cooler air movement, allow sufficient lighting, avoid offensive glare and reduce the sand and dust in prevalent winds. It has been used successfully in low-rise housing for centuries [22, 23].

In this paper, a description of a summer cooling of the house which is based on the malqaf theory is shown in Figure 6. Cooling is achieved through naturally pushing the air inside the house from the north-east side with a small water basin combined with a small fountain installed in the middle of the house down the malqf $[24,25]$.

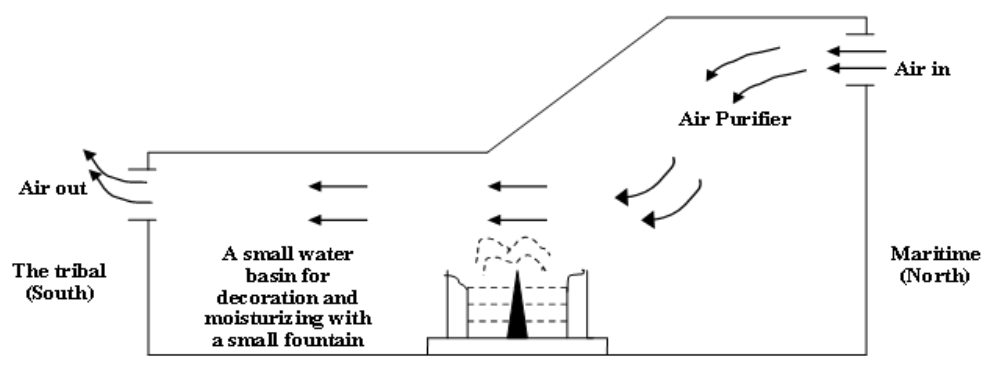

Figure 6. Natural air flow inside the house with a simple moisturizing process

\section{SIMULATION}

MATLAB software is used to simulate the performance of both the sheltered water storage tank and space heating system. Figure 7 shows Simulink block diagram of domestic sheltered water storage tank, which represents the water collector model. The inputs are the air temperature and solar radiation. The output is water temperature $\left(\mathrm{T}_{\mathrm{W}}\right)$. Figure 8 shows the space heating system model representation in Simulink: The model consists of space heating collector model, Pebble - bed storage unit mode, and house space heating radiator model. 


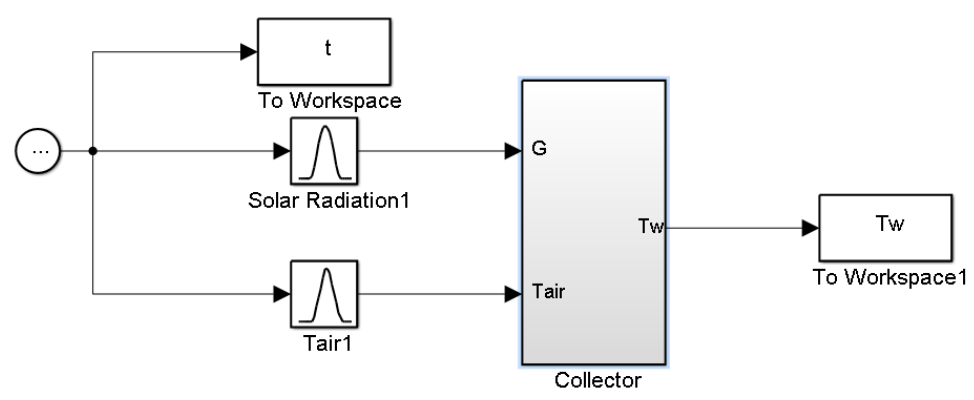

Figure 7. Simulink block diagram of domestic sheltered water storage tank

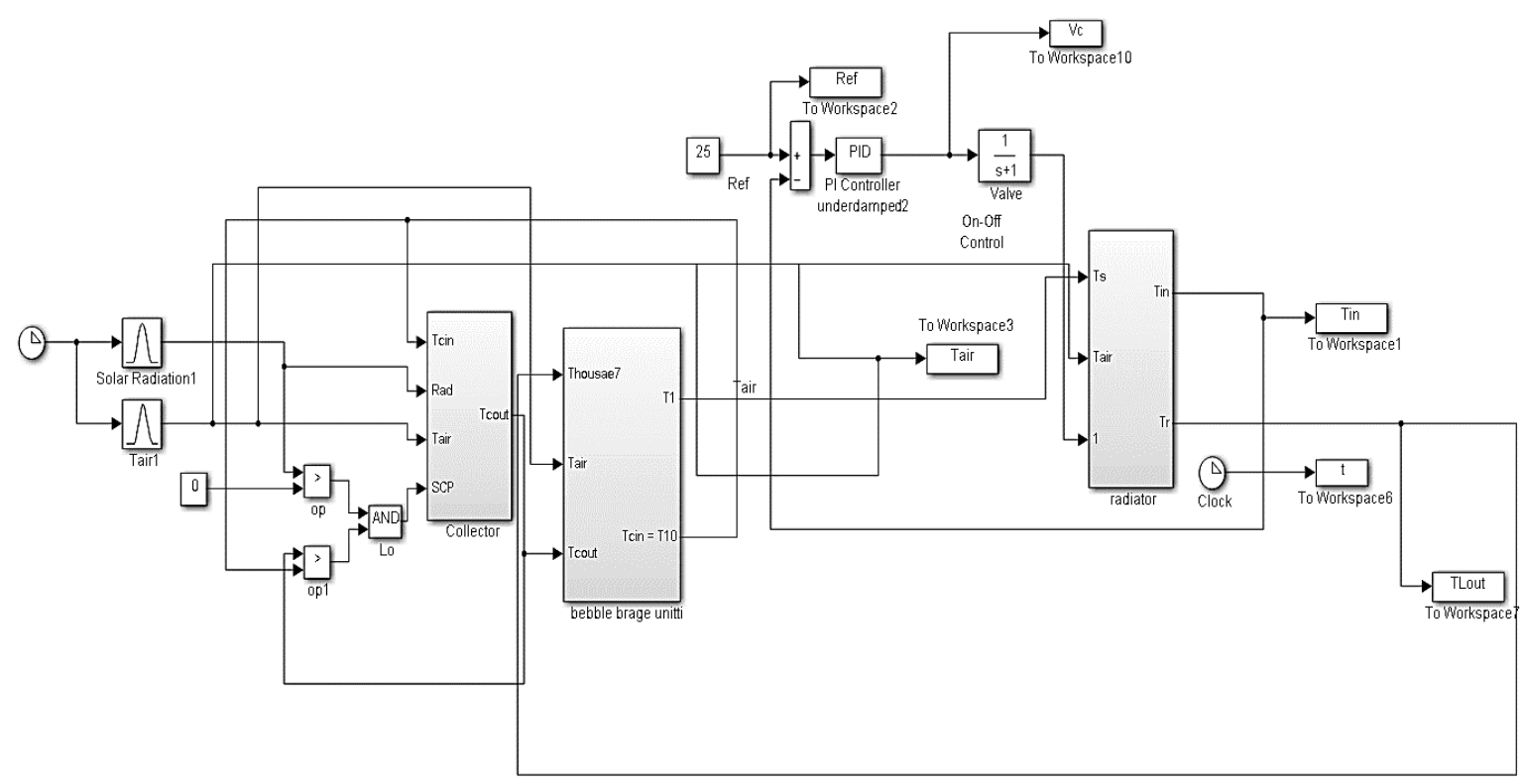

Figure 8. Simulink block diagram of space heating system

\section{RESULTS AND DISCUSSIONS}

The design space heating load calculations for the suggested solar house are shown in Table 2. The specifications of different components of proposed space heating system are illustrated in Table 3 . Figure 9 represents the indoor temperature using space heating sustem fixed at $25{ }^{\circ} \mathrm{C}$ throughout the day despite changing the atmospheric conditions.

Table 2. Heating load calculations

\begin{tabular}{|c|c|c|c|c|}
\hline Surface & $\begin{array}{c}\mathrm{U}(\mathrm{Btu}) \\
(\mathrm{hr})\left(\mathrm{ft}^{2}\right)\left({ }^{\circ} \mathrm{F}\right)\end{array}$ & $\mathrm{A}(\mathrm{ft} 2)$ & $\begin{array}{c}\Delta \mathrm{T}^{\circ} \mathrm{F} \\
\left(\mathrm{T}_{\mathrm{R}}-\mathrm{T}_{\mathrm{O}}\right)\end{array}$ & $\begin{array}{c}\mathrm{H}=\mathrm{UA} \Delta \mathrm{T} \\
\mathrm{But} / \mathrm{hr}\end{array}$ \\
\hline Exterior Wall (net) & 0.08 & $1205.4 \mathrm{ft}^{2}$ & 29 & 2796.528 \\
\hline Windows & 1.13 & $65 \mathrm{ft}^{2}$ & 29 & 2130.05 \\
\hline Doors & 0.49 & $147 \mathrm{ft}^{2}$ & 29 & 2088.87 \\
\hline Floors & 0.06 & $1007.73 \mathrm{ft}^{2}$ & 29 & 1753.4502 \\
\hline Ceiling & 0.05 & $1007.73 \mathrm{ft}^{2}$ & 29 & 1461.2085 \\
\hline Total & & & & 10230.1067 \\
\hline \multicolumn{4}{|l|}{ Infiltration } & 5177.5321767 \\
\hline \multicolumn{4}{|c|}{ Design Heating Load: Btu /hr } & 15407.6388767 \\
\hline \multicolumn{4}{|c|}{ Design heating load (Btu/DD) } & 12751.1494152 \\
\hline \multicolumn{4}{|c|}{ January bleating Load: $\mathrm{m}$ Btu(Btu/DD) $X($ January DD $=12751.15 * 276=$} & 3519317.2385952Btu \\
\hline
\end{tabular}


Table 3. Specifications of different constituents of the proposed space heating system

\begin{tabular}{ll}
\hline Items & Values \\
\hline Collector area & $95.1564 \mathrm{ft}^{2}=8.84 \mathrm{~m}^{2}$ \\
Casing and a absorber material & Aluminum. \\
Collector slope & $45^{\circ}$ \\
Collector air flow rate & $185.57 \mathrm{cfm}=0.08757929 \mathrm{~m}^{3} / \mathrm{s}$ \\
Pebble bed storage size & $79.53 \mathrm{ft}^{3}=2.252 \mathrm{~m}^{3}$ of rock \\
Pebble size & $0.875^{\prime \prime}=0.022225 \mathrm{~m}$ concrete aggregate \\
\hline
\end{tabular}

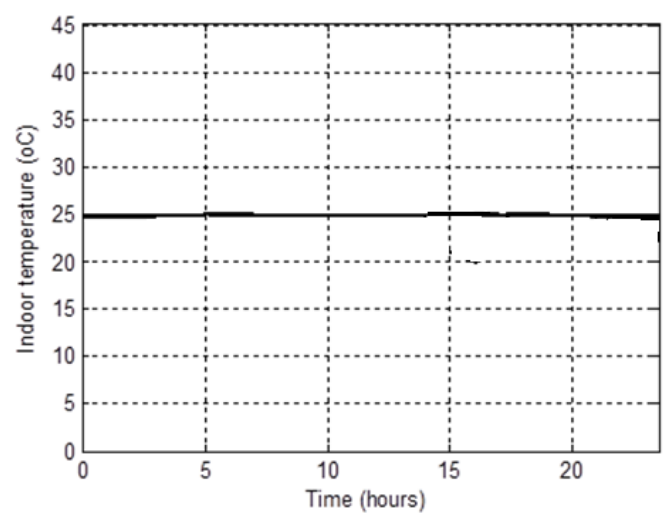

Figure 9. Solar house indoor temperature

Figures 10 and 11 represent the temperature difference of the air collector for air mass flow rates of 0.045 and $0.03 \mathrm{~kg} / \mathrm{s}$, respectively. It can be noted that the temperature difference decreases as the air mass flow rate increases. While, Figure 12 indicates the variation of thermal efficiency with time for different air mass flow rates. Air mass flow rate is very important for collector efficiency calculations. As can be seen in the Figure 10, the efficiency increases to a maximum value during the interval 12:30 to 1:30PM, then decreases towards the evening. The results show that the collector efficiency increases with the air mass flow rate and solar radiation increasing. The average efficiency calculated for air mass flow rate of $0.045 \mathrm{~kg} / \mathrm{s}$ is 0.63 . The average efficiency calculated for air mass flow rate of $0.025 \mathrm{~kg} / \mathrm{s}$ is 0.47 . According to the (6), this result can be explained by increasing the amount of heat absorbed by the collector with increase the intensity of the incident solar radiation during the daylight. Also, the amount of the absorbed heat is increased with increasing air mass flow rate.

Figures 13 and 14 show the performance of the sheltered water storage tank for water heating during the summer and winter days, respectively. It is indicated that the temperature of the water increases during daylight hours and decreases during the night hours. The heated water at the highest temperature $37^{\circ} \mathrm{C}$ and $52^{\circ} \mathrm{C}$ in winter and summer is available at $5 \mathrm{pm}$. This result can be attributed to the increase the amount of heat absorbed during daylight as given by (12).

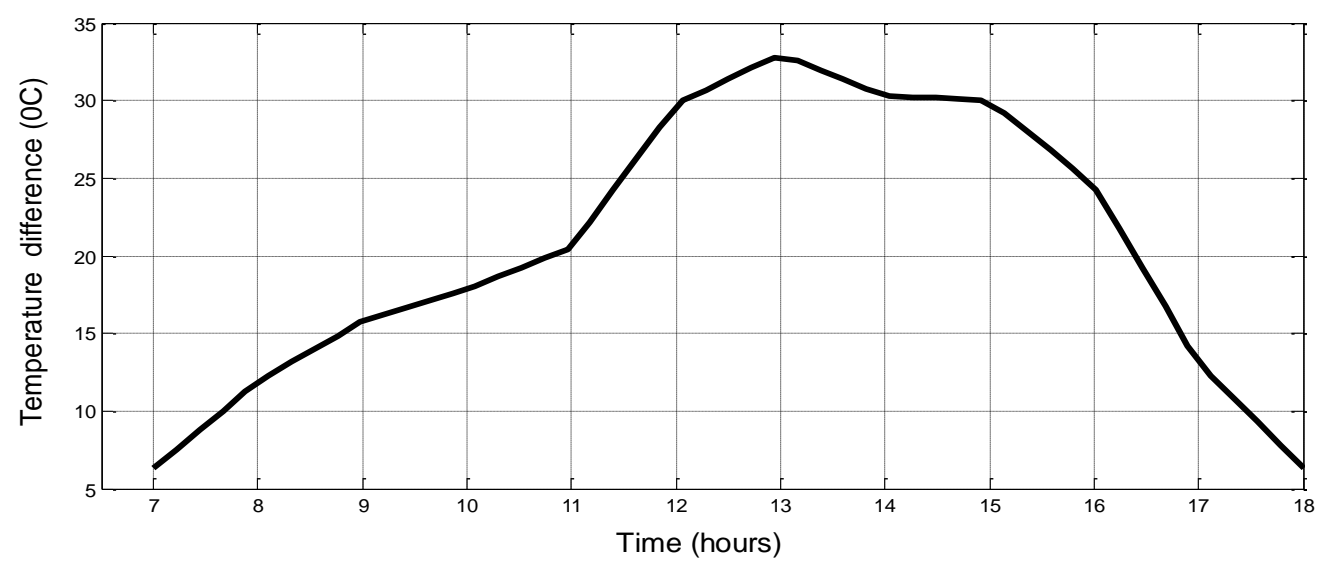

Figure10. Temperature difference for the air mass flow rate of $0.045 \mathrm{~kg} / \mathrm{s}$ 


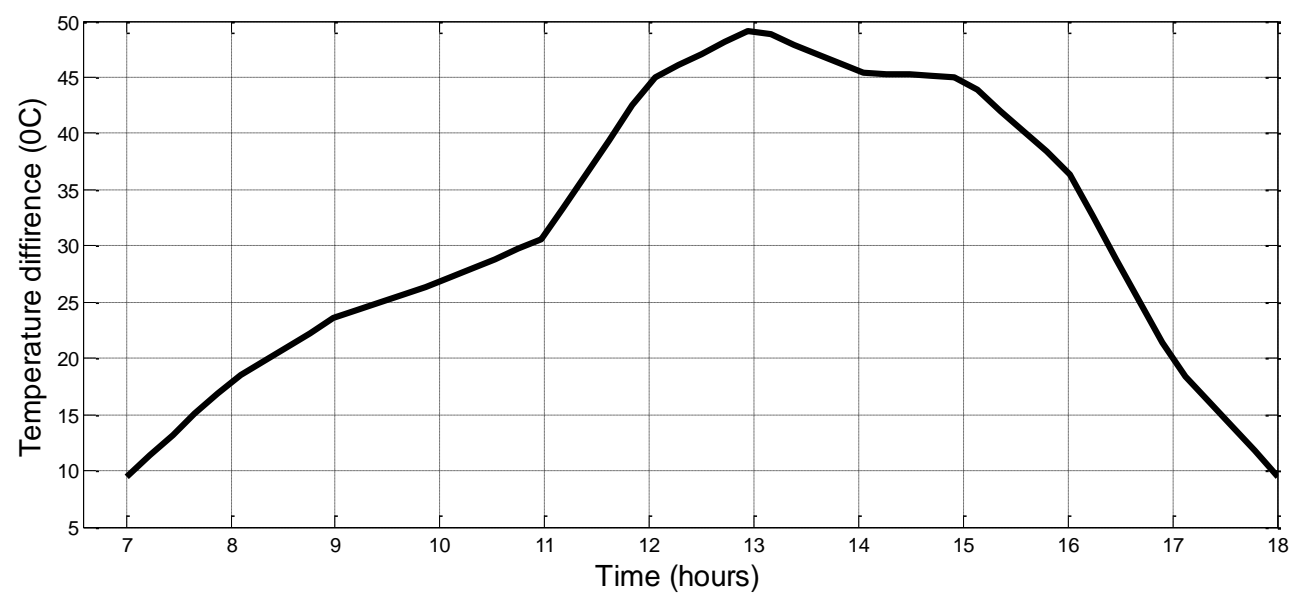

Figure11. Temperature difference for the air mass flow rate of $0.030 \mathrm{~kg} / \mathrm{s}$



Figure 12. Thermal efficiency at different air mass flow rates

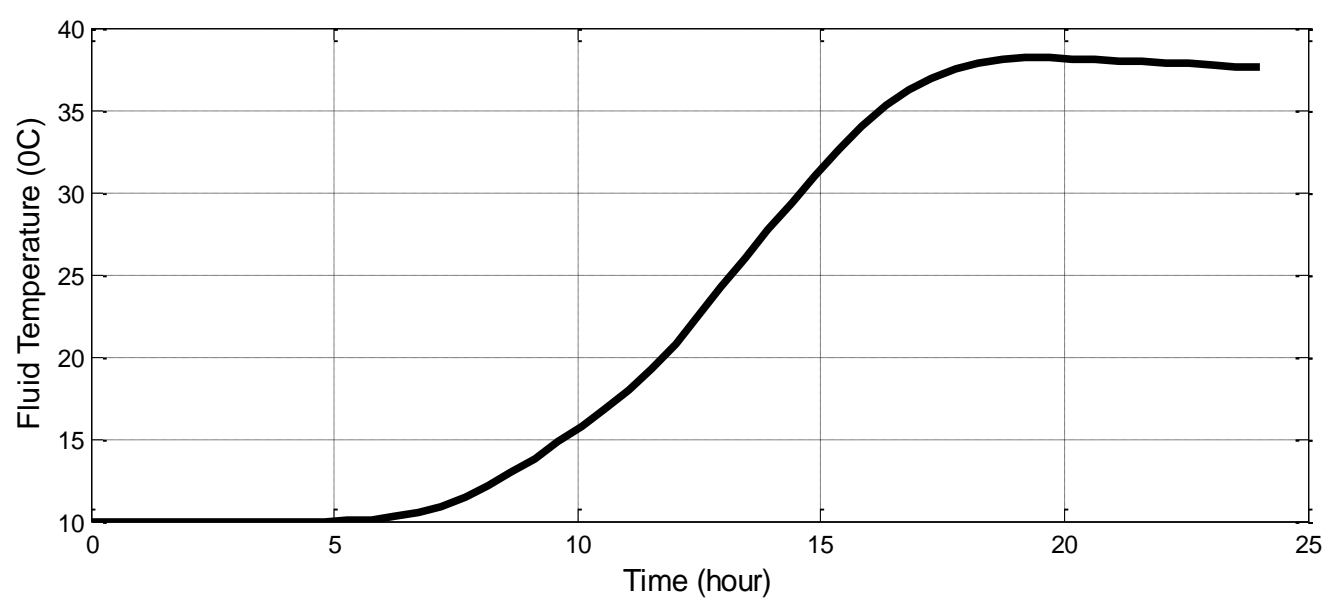

Figure 13. Evolution of fluid temperature of sheltered water storage tank in winter 


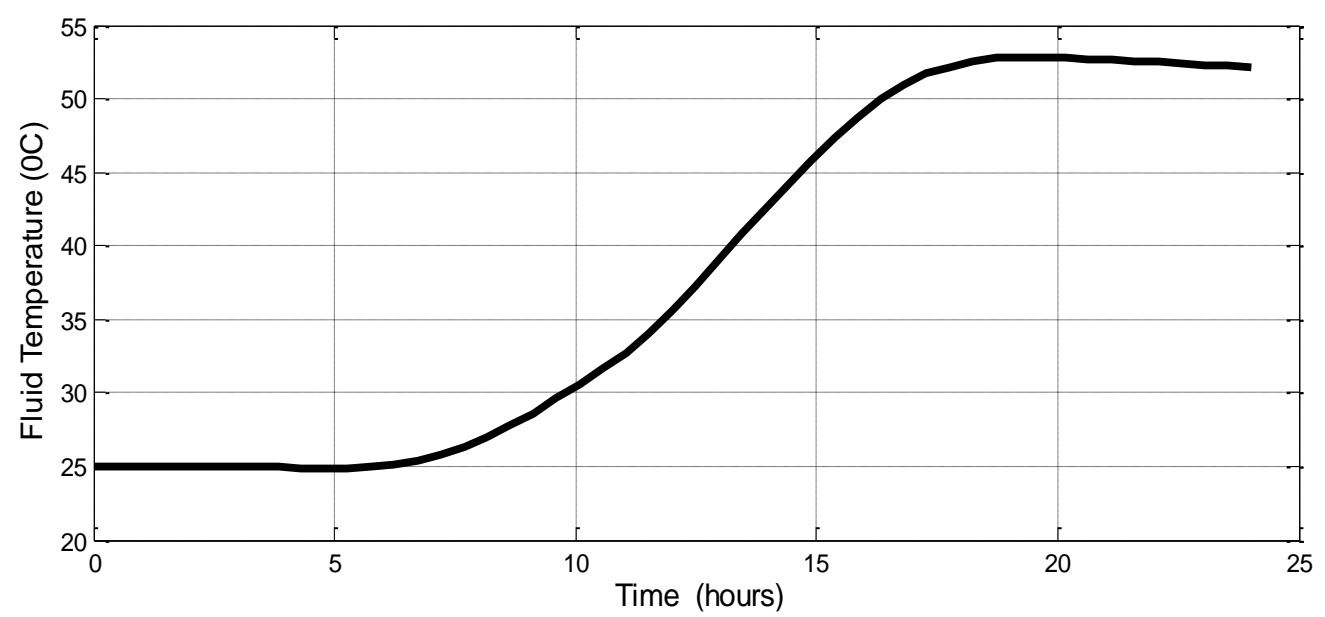

Figure14. Evolution of fluid temperature of sheltered water storage tank in summer

\section{CONCLUSION}

This paper presented the design of a modified two-story residential solar house of 110 square meters for a medium-size family located in Cairo, Egypt. A mathematical modeling and MATLAB Simulink model for both the sheltered water storage tank and solar air collector were presented. Space heating system collector efficiency increases with increasing air mass flow rate and solar radiation. The performance of the sheltered water storage tank shows that the used tank was able to heat the water that flows through it, whenever there is solar illumination; where the amount of heat absorbed by the water is proportional to the incident insolation levels. It can yield water temperatures in excess of $50^{\circ} \mathrm{C}$. The heated water at the highest temperature of $37^{\circ} \mathrm{C}$ and $52^{\circ} \mathrm{C}$ in winter and summer is available at $5 \mathrm{pm}$. The simple sheltered water storage tank proposed in this work can be used for domestic and industrial applications.

\section{REFERENCES}

[1] Lubna Hameed, Asad Ali Khan, "Population Growth and Increase in Domestic Electricity Consumption in Pakistan: A Case Study of Bahawalpur City," the Explorer Islamabad: Journal of Social Sciences, vol. 2, no. 1, pp. 27-33, 2016.

[2] Ioan Sarbu and Marius Adam," Applications of solar energy for domestichot-water and buildings heating/cooling"', international journal of energy, issue 2, vol. 5, 2011.

[3] Abdeen Mustafa Omer, "The Energy Crisis, the Role of Renewable and Global Warming," Greener Journal of Environment Management and Public Safety, vol. 1, no. 1, pp. 038-07, 2012.

[4] Alireza Gheiratmand, Reza Effatnejad, Mahdi Hedayati, "Technical and Economic Evaluation of Hybrid wind/PV/Battery Systems for Off-Grid Areas using HOMER Software", International Journal of Power Electronics and Drive System (IJPEDS), Vol. 7, No. 1, pp. 134-143, 2016.

[5] Krishan Arora*, Amardeep Singh Virdi, "Off-Grid Energy Technologies Used in Rural Areas of India”, Bulletin of Electrical Engineering and Informatics, Vol. 2, No. 3, pp. 190 193, 2013.

[6] "Various Disadvantages of Fossil Fuels," Conserve Energy Future, [Online] Available: https://www.conserveenergy-future.com/disadvantages_fossilfuels.php

[7] Ninet Mohamed Ahmed, Hanaa Mohamed Farghally, Faten Hosney Fahmy, "Optimal Sizing and Economical Analysis of PV-Wind Hybrid Power System for Water Irrigation using Genetic Algorithm," International Journal of Electrical and Computer Engineering (IJECE), vol. 7, no. 3, pp. 1797-1814, Aug. 2017.

[8] "Solar House - Student," The Environmental Literacy Council, [Online], Available: https://enviroliteracy.org/ teaching-resources/ap-environmental-science-course-material/solar-house-student-2/.

[9] Wendy Van Norden and Walter Werner, "Solar House Teacher," Lab Template, The Environmental Literacy Council, [Online], Available: https://enviroliteracy.org/teaching-resources/ap-environmental-sciencecourse-material/solar-house-student-2/

[10] J. A. Candanedo and A. K. Athienitis, "A systematic approach for energy design of advanced solar houses," in 2009 IEEE Electrical Power \& Energy Conference (EPEC), pp. 1-6, 2009.

[11] Offices- National Labs, "Passive Solar Home Design,” Energy.gov [Online], Available: https://www.energy.gov/ energysaver/energy-efficient-home-design/passive-solar-home-design.

[12] Han Li, Yue Liu, Yuting Bian, Ruonan Xu, "Research on the evaluation method of design scheme of solar house," Conference: 2014 26th Chinese Control and Decision Conference (CCDC), 2014.

[13] T. Yue, Y. Wang, and Y. Wang, "Research on the promotion of Solar Energy House," International Conference on Materials for Renewable Energy \& Environment, pp. 247-250, 2011. 
[14] W. O. Brien, A. Athienitis, and T. Kesik, "The Development of a Solar House Design Tool," Elev. Int. IBPSA Conf., 2009, pp. 1397-1404.

[15] M. A. Mosalam Shaltout, "Egyptian solar radiation atlas," New and Renewable Energy Authority, Ministry of Electricity and Energy : United States Agency for International Development, 1991.

[16] Y. Chen, A. K. Athienitis, K. E. Galal, and Y. Poissant, "Design and Simulation for a Solar House with Building Integrated Photovoltaic-Thermal System and Thermal Storage," in Proceedings of ISES World Congress 2007 (Vol. I - Vol. V), Berlin, Heidelberg: Springer Berlin Heidelberg, pp. 327-331, 2008.

[17] "Solar heating and cooling of residential buildings Sizing; installation and operation of systems," by Solar Energy Applications Laboratory Colorado State University, 1977.

[18] Pin-Yang Wang, Hong-Yang Guan, Zhen-Hua Liu, Guo-San Wang, Feng Zhao, Hong-Sheng Xiao, "High temperature collecting performance of a new all-glass evacuated tubular solar air heater with U-shaped tube heat exchanger," Energy Conversion and Management, vol. 77, pp. 315-323, Jan 2014.

[19] L. Simona Paraschiv, S. Paraschiv, Ion V. Ion, "Experimental and Theoretical Analyses on Thermal Performance of a Solar Air Collector,” Environ. Eng.Manag. J., vol. 13, no. 8, pp. 1965-1970, 2014

[20] John Twidell, Tony Weir, Renewable Energy Resources, Taylor \& Francis Group, London and New York, 2006.

[21] Ninet Mohamed Ahmed, Faten Hosney Fahmy, Hanaa Mohamed Farghally," Modeling and Control of Medical Herb Greenhouse based on Solar Thermal System", International Journal of Applied Engineering Research, Vol. 11, No. 5, pp 3042-3049, 2016.

[22] Abhishek Saxenal and Varun Goe, "Review Article Solar Air Heaters with Thermal Heat Storages," Chinese Journal of Engineering, pp. 1-11, 2013.

[23] Hanan M. Taleb, "Using passive cooling strategies to improve thermal performance and reduce energy consumption of residential buildings in U.A.E. buildings," Frontiers of Architectural Research, pp. 154-165, 2014.

[24] Shady Attia, André De Herde, "Designing the Malqaf for Summer Cooling in Low-Rise Housing, an Experimental Study," PLEA2009 - 26th Conference on Passive and Low Energy Architecture, Quebec City, Canada, Jun 2009.

[25] Ulrike Passe and Francine Battaglia, Designing Spaces for Natural Ventilation, an Architect's Guide, Taylor \& Francis group, New York and London, 2015.

\section{BIOGRAPHIES OF AUTHORS}

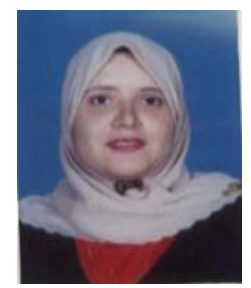

Dr. Hanaa M. Farghally received her B.Sc in electrical power and machines from the faculty of engineering, Helwan University in 2000. She awarded her MSc in 2005 in the field of medical herbs drying using renewable energy in remote area, from the faculty of engineering, Cairo University, while the Phd degree was awarded in 2009 in the field of optimization of renewable energy systems, from the faculty of engineering, Cairo University. She is currently an assistant professor in Photovoltaic cells department, Electronics Research Institute since 2015. Her experience is mainly in the field of design and optimization of renewable energy systems.

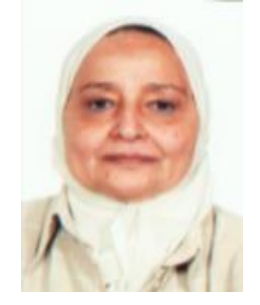

Prof. Faten HosneFahmy received her B.Sc in electrical power and machines from the faculty of engineering in 1972. Her MSc was in automatic control while the Phd degree was in the field of operation research and optimization. All the above degrees were received from the faculty of engineering, Cairo University. She is a professor in Electronic Research Institute. She was the women of the year 1998, listed in Five Hundred Leaders of the 20 th Century, Who's Who 99 Encyclopaedia. Her experience is mainly in the field of operation research and optimization. Also, in the field of renewable energy systems and applications.

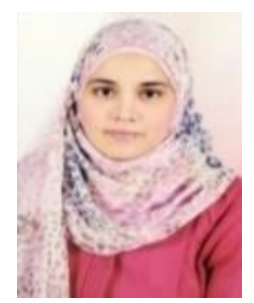

Amal A. Hassan received her B.Sc. in electrical power and machines from the Faculty of Engineering, Cairo university in 2003. She awarded her M.Sc. and Ph.D. in electrical power and machines from the Faculty of Engineering, Cairo university in 2009 and 2016, respectively. Currently, she is a researcher in Photovoltaic Cells Dept., Electronics Research Institute (ERI), Cairo, Egypt. Her research interests include grid connected PV systems, smart power grid, optimization and control of distributed generation based on renewable energy and micro grid, optimization and control of hybrid stand alone renewable energy systems and classical and intelligent optimization techniques.

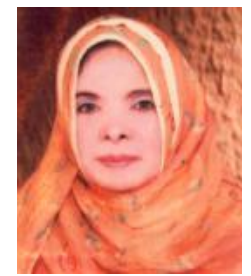

Prof. Ninet M. Ahmed received her B.Sc in Communication Dept., Faculty of Engineering, Helwan University, in May 1982, M.Sc in 1997 from Communication Dept., Faculty of Engineering, Ain Shams University. She was awarded her Ph.D. in Communication Dept., Faculty of Engineering, Tanta University in 2005. She is currently a professor at the Electronics Research Institute, Photovoltaic Cells Dept. since 2012. Her experience is mainly in the field of design and optimization of renewable energy systems, solar cells fabrication, thin films technologies and Microcontroller -based applications. 